\title{
The impact of ownership structure and bank loans on listed firms investment in Tehran Stock Exchange (TSE)
}

\author{
Faezeh MoHAMmadi $^{1}$, Ali EHTESHAMI ${ }^{2}$ \\ ${ }^{1}$ M.A student in accounting, Saveh Branch, Islamic Azad University, Saveh, Iran \\ ${ }^{2}$ Accounting Ph.D, Saveh Branch, Islamic Azad University, Saveh, Iran
}

\begin{abstract}
There are different theories in investigating and explaining the association between financing through debt and investment. Various experimental articles have studied this relation and the factors influencing it. In this study, we investigate the relationship between financing activities through bank loans and the listed companies investment in TSE. We divide the companies into two groups according to the ownership structure: companies with state ownership and non-state ownership. We have utilized the information related to 104 listed companies in TSE for the fiscal year 2008-2014. The research is descriptive-applied and ex-post facto and the combined multivariable regression has been used to test research hypothesis. The results show that the receivable loans ratio has a negative association with the company's investment ratio and this association is stronger for the companies with non-state ownership. As well, it can be said that companies having less investment ratio due to the projects with positive NPV, have more opportunities to growth according to Myers viewpoint.
\end{abstract}

Keywords: short-term financing, long-term financing, ownership structure, state ownership, investment activities

\section{Introduction}

Investment is one of the major elements of capital market. The main aim of every investor from investing is gaining the maximum return and productivity. In order to motivate the investors to invest their financial assets, the return on these assets should be more than other options (Abbasi et.al, (2010).

Value of a company is based on the profitability of its investments. So the managers with the aim of maximizing the shareholders wealth must identify the factors influencing the investment level to interact between the shareholders expectations and the desirable investing opportunities. In this case, the investors won't lose the profitable investment opportunities (Fazzari, 2000. Page 598). 
The managers provide the resources necessary to finance the projects with positive net present value by investment absorption but various factors affect the investment decisions of a company. These factors have an effect on the capital cost, profitability, shareholders expected benefit, share value of the company by affecting the investment projects selection of companies(Myers S., Majluf, N, 2006).

Before emerging big companies and late 18 century, there were owners, managers and ownermanagers, but with separation of ownership from management, the emergence of stock exchange markets and professional managers groups, a new approach introduced under the title of Joint StockCompany as social phenomena and caused the conflict of interests between the managers and the owners. Combination of shareholders in different countries may be different, however ,the shareholders have a basic role in the corporate governance system ,so their different combination in companies has different effects on performance of the companies, as well, the method of reflecting the firm's information in market and it's information symmetry. Meanwhile, the most attention getting thing is the increasing presence of institutional investors. For that reason, the performance monitoring method of company's management can be different due to the type of ownership. Institutional shareholders have the potential of having positive effect on the managers activities directly by ownership and indirectly by exchange of shares and the direct and indirect effect of institutional shareholders can be important.

We examine the relationship between financing activities especially bank loans and the investments of listed companies in TSE. We divide the companies into two groups according to the ownership structure. These groups include the companies with state-owned ownership and non- state-owned ownership.

Due to the results of previous researches, it is expected to be a meaningful and negative relationship between the bank loans and the company investment.

\section{Theoretical Foundations for Research}

Value of a company is based on the profitability of its investments. So the managers having the aim of maximizing the shareholders wealth must identify the factors influencing the investment level to interact between the shareholders expectations and the desirable investing opportunities. In this case, the investors won't lose the profitable investment opportunities.

The managers provide the resources necessary to finance the projects with positive net present value by investment absorption but various factors affect the investment decisions of a company. These factors influence the capital cost, profitability, shareholders expected benefit, share value of the company by affecting the investment projects selection of companies (Myers, S., Majluf N, 2006).

The necessary capital for different investment projects of the company is supplied by various groups of investors having different claims toward the future expected earnings of the company. 
These necessary aspects of the company may be supplied through the retained earnings of the company, new share selling, debts (loan facility and bonds) or combination of these resources.

The studies related to the effective factors for company investments and the method of resource provisioning by companies to invest in profitable projects in order to boost the company value, have emphasized on financing through the banks and the impact of company's financial leverage on investment decisions of company. There are two points of view in this regard. The first one stressed by Myers (1997) says that the company managers with high financial leverage focus on investing the projects with positive future cash flows net present value (NPV) because of higher debts/liabilities levels. So the companies having more financial leverage, less chances there are for them to grow compared to the companies with lower financial leverage. He stresses the liquidity on 'underinvestment theory'. The companies having more debt obligations, invest less without paying any attention to the nature of their growth opportunities.

The second viewpoint introduced by Jensen (1986) and Sultz (1990) says that the higher financial leverage prevents inappropriate use of free cash flow. The creditors compare the operation performed by the company via comparing the growth rate of the company and high leverage. The other agency problem based on agency theory is 'overinvestment' which forms depending on the conflicts between the managers and shareholders: the managers tend to maximize the company size, though they get forced into accepting weak projects and decrease shareholders wealth.

Aivazian et al (2005) founded that in Canadian companies the association between financial leverage and investment coincides with the second viewpoint. And according to another research performed in US, this relation coincides with the first point of view. These findings include the studies performed in developed countries and may not be extendable to the developing countries. Banks in developed economies, provide the necessary financial resources of companies, they seek to maximize their return on invested capital(ROIC) in companies but the financing markets are usually new in developing countries and include the commercial banks controlled by public sector and their aim is not gaining the maximum return(Tehrani \& Hesarzadeh, 2009).

Due to the type of ownership, the method of performance monitoring of companies management can be different. Meanwhile, what gets more attention is the increasing presence of institutional investors in owner's domain of public joint stock companies and their active role in the group for governance method inside the organizations and also their performance. The institutional shareholders have an effective ability to impact the managers activity directly by ownership and indirectly by share exchange and direct and indirect influence of state shareholders can be very important (Dinc (2005), Sapienza (2004), LaPorta et al.(2002))

Institutional investors are big investors such as banks, insurance companies, investment companies, pension fund, etc... that due to having a considerable ownership of company's share, have a great influence in investee companies and they can influence their approaches. These types of investors are considered as the professional shareholders and have strong analyzers who analyze accounting information, and they have the ability of using these information.

In this study, the share ratio in control of these shareholders to the whole share of company is considered as the institutional investor's variable. The institutional investors possess the required 
potential and ability to monitor the companies usually due to having a considerable percentage in company share and also being professional in the investment matter.

In this study, we investigate the relationship between bank loans and the investment of listed companies in TSE. We divide the companies into two groups according to the ownership structure: the companies with state-owned ownership and non-state-owned ownership.

In previous researches, the association between financial leverage and company investment for companies having state ownership and non-state ownership has been studied individually and in different countries. In this research, we examine and compare this relationship between these two groups of companies (state ownership and non-state ownership).

According to the above mentioned materials and the results of previous researches, it is expected to be a negative and meaningful relationship between bank loans and company investment. It is also expected to be a weak relationship in companies with state ownership.

\section{Research History}

Pandey, I.M (2014) found a spatial relationship (Cubic) between growth opportunities and debt. He reasoned that agency problems about the relationship between shareholders and managers and between debtors and shareholders/managers, may limit the financing of growth opportunities through debts and this influence may depend on the level of growth opportunities. Wei Jiang and Yeqin Zeng (2014) in their research under the title of " investigating the effect of ownership structure of bank loans on companies investment in China including the data from 2000-2011", found that there is a negative and meaningful relationship between bank loans and company investments. This association is true for both short-term and long-term bank loans. Their findings also showed that the ownership structure is true just for short-term loans and the relationship between bank loans and investment in companies with state ownership is weaker than the companies with non-state ownership. And finally the companies with lower growth rate have stronger relationship. Ce'spedes et al. (2010) examined the relationship between the capital structure and ownership in 7 Latin American countries and resulted that there is a positive relationship between leverage and ownership concentration. The results also show a positive relationship between the leverage and growth variable and a negative relationship between the leverage and profitability and bigger companies have higher tangibleassets. Bei \& Wijewardana (2012) deduced from the results of their studies that first, there is a positive relationship between high earning growth rate and financial leverage degree(Total Debts to Total Assets) and this reasoning doesn't cover other standards for financial leverage and growth rate.

Second, the companies with high sale growth rate and financial capability tend to have a low financial leverage ratio because of higher investment in stock, high sale growth rate and financial capability. Vmuthe (2009) examined the leverage effect on the investment in emerging markets. He reasons that the leverage influence on investment is important because the firm 's value is determined through the expected cash flows gained from investments but the channel from 
which the leverage influences the capital is not defined. Anyway, the manager doesn't tend the investment to be financed by debts because the creditors would take a share in investments output. So, increasing the debt ratio, managers may not execute suitable investments that lead to decreased company value. Appositional theory to correlate between the leverage and investment comes from the benefits conflict between shareholders and manager. Managers prefer to extend companies size (and they like to boost their power in the company), even if this leads to lose the shareholders wealth (and also company value decrease because of accepting weak projects). Sung C. Bae (2009) experimentally examined the relationship between financial leverage and investment opportunities in china industrial companies.

According to him, it is expected that the china companies who have more growth opportunities, have low tendency to get loan, also big companies use more debts but small companies use their own funds. Hoshi(1991) showed that for companies having a low debt rate and a high dividend, investment level is additive. Also there is an inverse interaction between debt ratios and investment opportunities.

Tavakolnia et al. (2014) investigated the financial leverage and it's connection with financial capability, growth and heavy investment in fixed assets of firms listed in TSE. The sample size included 110 firms listed in TSE in 2007-2011.

The regression method is applied for testing the theories. The research results show that the growth has no influence on financial leverage and the financial capability has a positive influence on the financial leverage. Also, it shows that there is a U-form connection between the fixed assets and the financial leverage in the listed companies in TSE. Mahmoudi et al. (2013) in a research under the title of investigating the interaction between the growth rate (low) and debt in the firms listed in TSE examined the connection between the growth opportunity and debt in the low level of growth opportunity by applying the information related to 81 firms listed in TSE in 2005-2012. These data have been extracted from the financial statements existing in databases like Tadbir-Pardaz software. The multi-variable regression is used to test the research theories. The research results of theory testing show that in companies having a law level of growth opportunity, there is a negative and meaningful association between the growth rate and the level of debt leverage. Noravesh and Yazdani(2010) examined the connection between the leverage and investment decisions in the firms listed in TSE. For this purpose, they used two size of leverage and three experimental model. Their results showed that there is a negative and meaningful interaction between the leverage and investment. The results also showed that the connection of investment leverage for companies with a less growth opportunity is stronger for the companies with a high growth opportunity.

\section{Research theories}

1) There is a negative and meaningful interaction between Bank Loans and company investment. 
2) The interaction between the amount of bank loans and investment in the companies having on institutional ownership is weaker compared to the companies having non-institutional ownership.

\section{Statistical Population}

The statistical population includes the whole companies active in the listed companies in TSE during 2008-2014 and the statistical sample is determined by adjusting this population from a set of limitations mentioned in the following.

\section{Statistical Sample}

In this research the sample selected with a whole statistical population including the firms listed in TSE during 2008-2014 and the following cases were considered:

1) The firms must be listed in TSE organization before 2014.

2) The firms must not be eliminated from TSE during the research course.

3) The required financial information must be completely available for the research during 20082014.

4) The firms must not be among the financial intermediation, investment companies including banks and insurances because of their different pricing method.

5) The companies must end their fiscal year on the final day of February.

Due to the limitations of research, the sample number includes 104 companies listed in TSE.

\section{Data Analysis}

For the sample number (observations) to be independent from each other and the sample be random for testing, Durbin-Watson test is applied. The coefficients of the regression model variables are tested using the Student's-T-Test. In this study, the Fisher-statistic is used with 95\% of accuracy to test the meaningfulness of the regression model. The Durbin-Watson test is applied to test the non-correlation existence among the model errors. Finally, the error components curve was designed to examine the normality of error components. We test the hypotheses by the linear regression method. The multi-variable regression is applied as the statistical method. We study whether there is a relationship between dependent variables and independent variables or not. Also, the data analysis in the descriptive statistics part will be started by calculating the central indexes including the average, median and dispersion Indexes of skewness standard deviation and measure of skewness. The combined data will be applied to test the hypotheses. In combined method, F (Limer) Test is used to select between the Panel and Pooling methods. In case of selecting the Panel method, the Hausman Test is performed to choose among the fixed effects and random effects methods. The collected data using Excel software will be entered into Eviews 7 software after the required corrections and classifications 
based on the examined variables and the final analysis will be executed. Then we will confirm or reject the hypotheses applying the results from the related softwares.

The following models (Aivazian et al. (2005), Ahn et al. (2006), and Firth et al. (2008)) are applied to test the research hypotheses:

$$
\begin{aligned}
\text { Investment }_{\mathrm{it}} & =\beta_{0}+\beta_{1} \text { Debt }_{\mathrm{it}-1}+\beta_{2} \mathrm{Q}_{\mathrm{it}-1}+\beta_{3} \text { Topshare }_{\mathrm{it}}+\beta_{4} \text { Bsize }_{\mathrm{it}}+\beta_{5} \mathrm{CF}_{\mathrm{it}}+\beta_{6} \text { Sales }_{\mathrm{it}} \\
& +\beta_{7} \text { Roa }_{\mathrm{it}}+\beta_{\mathrm{g}} \text { Size }_{\mathrm{it}}+\beta_{9} \text { Market }_{\mathrm{it}}+\varepsilon_{\mathrm{it}}
\end{aligned}
$$

That:

Investment: Company's net investment divided into the fixed assets

Debt: whole bank Loans ratio to book value of assets

\begin{tabular}{|l|}
\hline Q: Tobin Q index which is calculated as below: \\
\hline $\mathrm{Q}_{\mathrm{t}}=\frac{\mathrm{MV}+\mathrm{D}}{\mathrm{BV}}$ \\
\hline D: Book value of liabilities \\
$\mathrm{MV}$; Company's market value \\
BV: Assets book value
\end{tabular}

Topshare: share percentage of the biggest shareholder (Majorshareholder)

Bsize: the natural logarithm of members of director board

CF: Operating cash flow ratio to fixed assets

Sales: sales divided into the fixed assets

Roa: earning ratio to book value asset

Size: the natural logarithm of assets

Market: income percentage of the company sales to industry sales

The association between the bank loans and the company investment will be studied.

To test the second hypothesis and the state ownership effect on this relationship, the interaction between the bank loans and the company investment by separation of state and non- state ownership will be examined.

To classify this year, the companies are divided into two groups of state ownership and non-state ownership. First, the percentage of the state ownership of each company is calculated and then to examine the state ownership effect, the companies are classified using a dummy variable (Zero and One) into two groups with state ownership (One) and non-state ownership (Zero) based on 
the median of this variable. Then the model is evaluated for these two groups with the state ownership higher than median and less than median.

(Decision making toward confirmation or rejection of the hypotheses is based on the beta coefficient)

\section{Research Hypotheses Test}

\subsection{Descriptive Statistic}

Descriptive Statistic shows the numbers related to the dispersion and central index. Awareness of the descriptive statistics is a step to understand the average of data process and the interactions among them and also the approximate investigation of the distribution status. In this part, the most important descriptive statistic related to the case study variables is explained.

Table 1: Descriptive Statistic

\begin{tabular}{|c|c|c|c|c|c|c|}
\hline & $\begin{array}{c}\text { Investment } \\
\text { Ratio }\end{array}$ & Bank Loans & Tobin Q & $\begin{array}{c}\text { Major } \\
\text { Shareholder }\end{array}$ & State ownership & \\
\hline Average & 0.088077 & 0.262651 & 2.491209 & 0.393668 & 0.357445 & \\
\hline Median & 0.050000 & 0.220000 & 1.840000 & 0.390000 & 0.330000 & \\
\hline Maximum & 0.840000 & 2.580000 & 31.66000 & 0.750000 & 0.890000 & \\
\hline Minimum & 0.000000 & 0.000000 & 0.570000 & 0.080000 & 0.070000 & \\
\hline $\begin{array}{l}\text { Standard } \\
\text { Deviation }\end{array}$ & 0.115403 & 0.227944 & 2.517357 & 0.145293 & 0.177725 & \\
\hline Skewness & 2.387968 & 3.992104 & 6.052908 & -0.029497 & 0.623642 & \\
\hline Elongation & 10.37858 & 32.60515 & 55.29819 & 2.126101 & 2.616883 & \\
\hline Jarquebera & 2343.340 & 28519.78 & 87410.10 & 23.27111 & 51.64241 & \\
\hline $\begin{array}{l}\text { Jarquebera } \\
\text { probability }\end{array}$ & 0.000000 & 0.000000 & 0.000000 & 0.000009 & 0.000000 & \\
\hline \multirow[t]{2}{*}{ Observations No. } & 728 & 728 & 728 & 728 & 728 & \\
\hline & $\begin{array}{c}\text { the natural } \\
\text { logarithm of } \\
\text { members of } \\
\text { directors board }\end{array}$ & $\begin{array}{c}\text { Operational } \\
\text { cash flow ratio }\end{array}$ & $\begin{array}{l}\text { sales divided } \\
\text { into the fixed } \\
\text { assets }\end{array}$ & Return on Asset & $\begin{array}{c}\text { the natural } \\
\text { logarithm of } \\
\text { Assets }\end{array}$ & $\begin{array}{c}\text { income percentage of } \\
\text { the company sales to } \\
\text { industry sales }\end{array}$ \\
\hline Average & 1.788324 & 0.696154 & 6.440124 & 0.103984 & 13.50126 & 0.221113 \\
\hline Median & 1.790000 & 0.440000 & 4.430000 & 0.090000 & 13.26500 & 0.090000 \\
\hline Maximum & 1.950000 & 12.87000 & 71.70000 & 0.640000 & 18.82000 & 1.000000 \\
\hline Minimum & 1.610000 & -16.42000 & 0.080000 & -0.340000 & 9.880000 & 0.000000 \\
\hline $\begin{array}{l}\text { Standard } \\
\text { Deviation }\end{array}$ & 0.137863 & 1.549611 & 7.468516 & 0.129995 & 1.659454 & 0.301564 \\
\hline Skewness & -0.127156 & -0.092131 & 4.219767 & 0.496367 & 0.911800 & 1.624807 \\
\hline Elongation & 1.534281 & 34.06508 & 27.85765 & 4.732178 & 3.919687 & 4.346845 \\
\hline Jarquebera & 67.12787 & 29273.88 & 20903.56 & 120.9075 & 126.5307 & 375.3441 \\
\hline $\begin{array}{l}\text { Jarquebera } \\
\text { Probability }\end{array}$ & 0.000000 & 0.000000 & 0.000000 & 0.000000 & 0.000000 & 0.000000 \\
\hline Observations No. & 728 & 728 & 728 & 728 & 728 & 728 \\
\hline
\end{tabular}




\subsection{Inferential Statistics}

The F-Limer test is applied to choose between the panel regression models and the joint data model. If the joint data method is selected in F-Limer test, everything is ok, but if the the panel regression is selected, the Hausman test is required to be performed. The Hausman Test is used to determine whether to use the fixed effects model against random effects model or not.(Aflatooni and Nokbakht, 2010).

Before estimating the first model, it is necessary to perform the F-Limer test to investigate whether to use the panel data against the joint data for the above model or not.

Table 2: F-Limer test results

\begin{tabular}{|c|c|c|c|c|c|}
\hline Accepted Method & Error Level & $\begin{array}{c}\text { Freedom } \\
\text { Degree }\end{array}$ & $\begin{array}{c}\text { Statistic } \\
\text { Amount }\end{array}$ & Statistic & $\begin{array}{c}\text { Research } \\
\text { Model }\end{array}$ \\
\hline \multirow{2}{*}{ Panel Data Method } & 0.0000 & $(103,724)$ & 3.02 & StatisticF & First \\
\cline { 2 - 5 } & 0.0000 & 103 & 297.97 & $\begin{array}{c}\text { Chi square } \\
\text { statistic }\end{array}$ & Hypothesis \\
\hline Panel Data Method & 0.0015 & $(103.745)$ & 4.09 & Statistic F & $\begin{array}{c}\text { Second } \\
\text { Hypothesis }\end{array}$ \\
\hline
\end{tabular}

As you see, the results show that the $\mathrm{H} 0$ is rejected. As a result, the panel data method is preferred (the statistic error level of Limer test is 5\%). Now it is necessary that in continue the Housman test to be performed to select among the panel data method with fixed effects against the panel data method with random effects.

Table 3: The Housman test results-Studying the fixed-random effects

\begin{tabular}{|c|c|c|c|c|}
\hline Error Level & Freedom Degree & $\begin{array}{c}\text { Statistic } \\
\text { Amount }\end{array}$ & Statistic & Research Model \\
\hline panel data with fixed effects & 0.0088 & $(103,723)$ & 5.53 & First Hypothesis \\
\hline panel data with fixed effects & 0.0002 & $(103,211)$ & 5.33 & $\begin{array}{c}\text { Second } \\
\text { Hypothesis }\end{array}$ \\
\hline
\end{tabular}

As you see, the error level of Housman statistic level is less than 5\%, so the results indicate the rejection of $\mathrm{H} 0$, as a result the panel data model with fixed effects is preferred for all research models.

The results from Regression 
There is a negative and meaningful association between the bank loans and company investments.

Table 4: Summary of model (fixed effects panel)- dependent variable of investment ratio

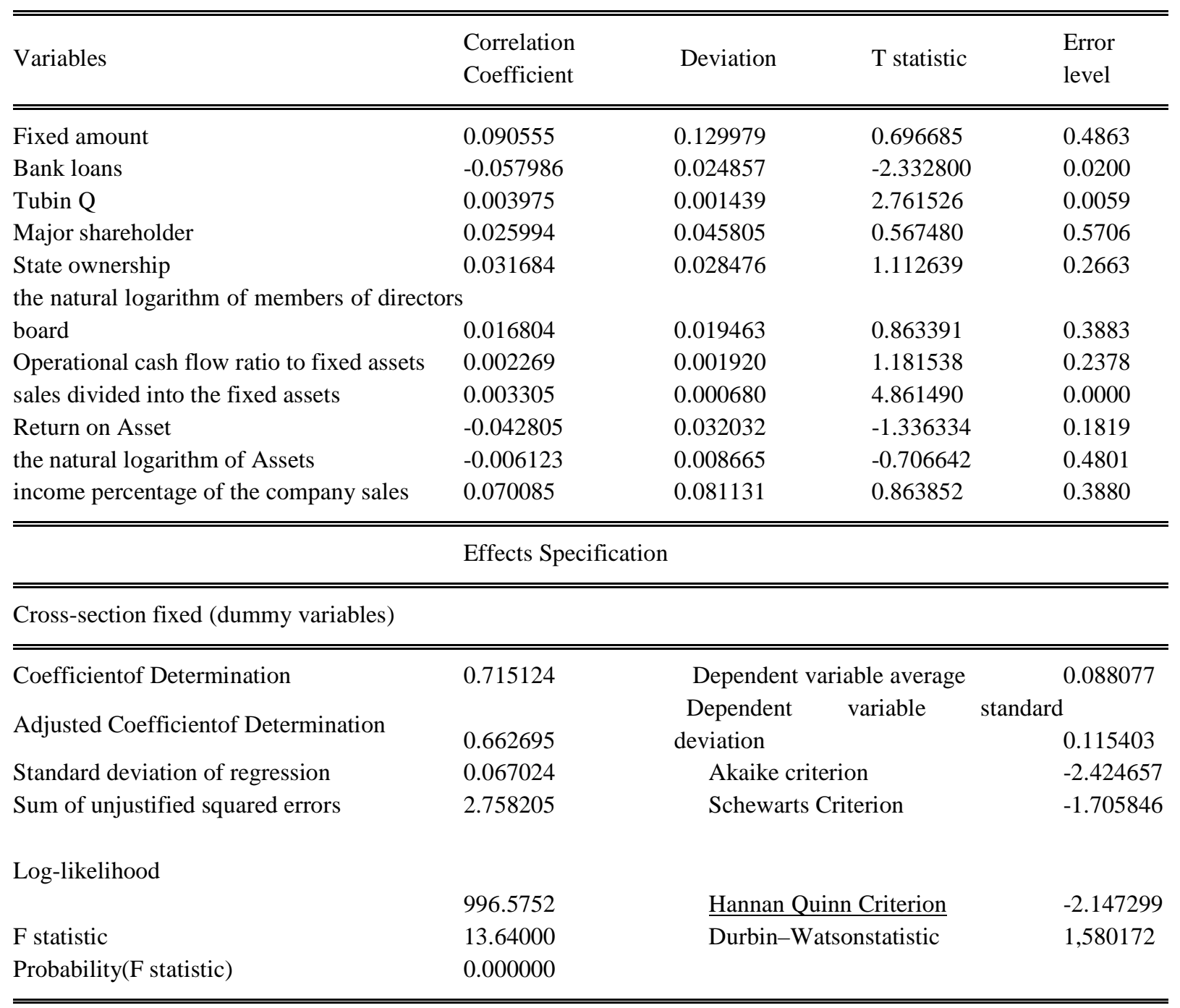

Test analysis of H1: The results from fitting the combined data regression by considering the investment ratio as dependent variable (table 4-5) shows that the adjusted determination coefficient is $66 \%$ meaning that the explanatory variable is able to predict the dependent variable up to $66 \%$ and this coefficient shows the model's efficacy. As well, to study the wrong phrases correlation, the Durbin-Watson statistic for 1.58 should be taken into account and because it is in span of 2.5-1.5, the correlation assumption of wrong phrases are rejected. Due to the fact that the meaningfulness level of $\mathrm{F}$ statistic is less than 0.05 , we get the result that the control and independent variables have a linear relationship with the dependent variable of the model. 
Now, to reject or confirm the hypotheses, we study the meaning fullness of variable the variables coefficient. \&Due to the fact that the correlation coefficient of the bank loan and dependent variable is $5 \%$ and the statistic of $\mathrm{T}$-student is negative and considering that the meaning fullness level of $\mathrm{T}$ - statistic is less than $5 \%$ (the accepted de error level),it shows that the bank loan variable has a negative relationship with company investment and this contraction is meaning ful in terms of statistic, as a result the first hypothesis is confirmed.

The negative relationship between the bank loans amount and the investment in companies having the institutional ownership is weaker that the companies with noninstitutional ownership.

Table 5: Summary of model (fixed effects panel)- dependent variable of investment ratio

\begin{tabular}{lllll}
\hline \hline Variables & $\begin{array}{l}\text { Correlation } \\
\text { Coefficient }\end{array}$ & Deviation & T statistic & $\begin{array}{l}\text { Error } \\
\text { level }\end{array}$ \\
\hline \hline Fixed amount & 0.090849 & 0.130163 & 0.697966 & 0.4855 \\
Bank loans & -0.056572 & 0.032960 & -1.716387 & 0.0866 \\
Tubin Q & -0.058469 & 0.025946 & -2.253463 & 0.0246 \\
Major shareholder & 0.003964 & 0.001449 & 2.735773 & 0.0064 \\
State ownership & 0.025749 & 0.045995 & 0.559829 & 0.5758 \\
the natural logarithm of members of directors & 0.031014 & 0.030279 & 1.024276 & 0.3061 \\
board & 0.016820 & 0.019480 & 0.863436 & 0.3882 \\
Operational cash flow ratio to fixed assets & 0.002271 & 0.001922 & 1.181522 & 0.2379 \\
sales divided into the fixed assets & 0.003304 & 0.000681 & 4.853693 & 0.0000 \\
Return on Asset & -0.042641 & 0.032156 & -1.326062 & 0.1853 \\
the natural logarithm of Assets & -0.006130 & 0.008673 & -0.706804 & 0.4800 \\
income percentage of the company sales & 0.070185 & 0.081211 & 0.864231 & 0.3878 \\
Fixed amount & & & \\
\hline \hline
\end{tabular}

Effects Specification

Cross-section fixed (dummy variables)

\begin{tabular}{|c|c|c|c|}
\hline Coefficientof Determination & 0.715126 & Dependent variable average & 0.088077 \\
\hline Adjusted Coefficientof Determination & 0.662147 & $\begin{array}{l}\text { Dependent } \quad \text { variable } \\
\text { deviation }\end{array}$ & standard $_{0.115403}$ \\
\hline Standard deviation of regression & 0.067078 & Akaikecriterion & -2.421917 \\
\hline Sum of unjustified squared errors & 2.758185 & Schewarts Criterion & -1.696801 \\
\hline \multirow[t]{2}{*}{ Log-likelihood } & 996.5778 & & -2.142126 \\
\hline & & $\underline{\text { Hannan Quinn Criterion }}$ & \\
\hline F statistic & 13.49846 & Durbin-Watsonstatistic & 1,879607 \\
\hline Probability(F statistic) & 0.000000 & & \\
\hline
\end{tabular}


Test analysis of $\mathrm{H} 2$ : the results from fitting the regression model shows that the adjusted determination coefficient is $66 \%$ and it indicates the models efficacy. As well ,to study the wrong phrase correlation, the Durbin- Watson statistic for 1.87 should be taken into account and because. It is in the span of 2.5-1.5, the correlation of wrong phrase are rejected. Due to the fact that the meaning fullness level of F statistic is less than 0.05 , we get the result that the control and independent variables have a linear relationship with the dependent variable of the model.

No, to reject or confirm the hypotheses, we study the meaningfulness of the variables coefficient. Due to the fact that the meaning fullness level of bank loans variable of the companies having the institutional ownership is higher than 5\%(the accepted error level), it shows no relationship between these two variables, but from one point of view, the bank bans variable of the companies having non - institutional ownership has a negative and meaningful relationship with the investment ratio showing that there is a stronger interaction, as a result the second hypothesis is confirmed.

\section{Result}

Considering the fact that the management of economic units are responsible toward the resources they possess, so the amounts receivable from banks incur high costs, so the manager must invest these resources in investment projects to have high earning, supply cost for debts liabilities and also excess shares for the company But it's interesting to know that the management has two solution for investment. First, he/she should accept every investment, in this case the investment ratio of the company increases. But in the second solution, accepting the investments is positive with net cash flows and in this case, the investment ratio decreases. The studies related to the factors influencing the company investment and the resources supplying method by companies to invest in profitable projects in order to increase the firm value have strongly emphasized the financing by the banks and the financial leverage effect of company on the investment decisions. There are two points of view in this regard. The first one provided by Myers (1997) says that the managers having high financial leverage companies focus on the investment projects with positive future cash flows of Net present value (NPV) because of higher debts amount. Therefore, the companies having a higher financial leverage amount will experience more growth opportunities relative to the companies having lower financial leverage amount. $\mathrm{He}$ focuses on liquidity effects in the theory of under investments: the companies having higher debt obligations invest less regardless of their growth opportunities nature. The second point of view discussed by Jensen and Stulz says that the higher financial leverage prevents from inappropriate use of free cash flow. The creditors compare the operations performed by company through comparing the company's growth rate and its high leverage. Another agency problem based on the agency is over investment which forms based on the conflicts between managers and share holders: the managers tend to extend company size even though they are forced to accept weak projects and decrease share holders wealth this study supports myers point of view, because of a negative relationship between the receivable loans ratio leverage and investment ratio, i.e. the companies with higher loans ratio just accept the projects with positive NPV and prevent the 
projects having negative NPV. So, according to the results, it can be said that the leveraging companies fallow the under investment theory.

\section{Practical Suggestions and Recommendations for Future Research}

1) Due to the negative contraction between the bank loans and investment, it is recommended that the managers accept the projects with positive NPV.

2) Due to the less resources and lower supervision or influence power for companies with noninstitutional ownership, it is recommended that the managers accept the more profitable investments.

3)The major risk of increased debts is inability to return the principal and interest in due date. So it is recommended that the managers finance through enterprise internal resources (operational cash flow).

4) Due to the changing effect of factors on growth opportunities like the social-political and economical situations, this research subject can be studied by researches in the future and compared with present research.

5) investigating the most appropriate approach for measuring the financial leverage and growth opportunities in TSE with other companies will be possible considering the factors such as firm size and type of industry.

6) studying the relationship between bank loans and investment ratio within investment and insurance companies having mare important owner ship influence can be the subject of future researches.

\section{Resources}

1. Tavakolnia, Esmail, Fazollah poor Nagharchi, Mehran \& Javid Hatam (2014), financial leverage and it s connection with financial capability, growth and heavy investment in fixed assets of the firms listed in TSE, financial management strategy. Social - economical campus of Alzahra university.

2. Tehrani, Reza \&Reza Hesarzadeh (2009), the influence of cash flows and the financing limitations on overinvestment and under investment, accounting researches, no.3, page33.

3. Abbasi, Ebrahim \& Ebrahimzadeh pour(2010),investigating the effective factors on investment level in TSE, Quarterly journal of economical modeling, third year, No.4, page62-49.

4. Mahmoudi, Abolfazl, Yaser Haghighi, Seyed Mohsen Karimian Moghadam \& Azadeh Rafee (2013), studying the relationship between low growth opportunities and debt in the firms listed in TSE, the eleventh international conference of accounting in Iran, Mashhad and Ferdousi university of Mashhad. 
Bulletin de la Société Royale des Sciences de Liège, Vol. 86, special edition, 2017, p. 206 - 219

5. Noravesh \&Yazdani(2010), investigating the financial leverage impact on the investment in the companies listed in TSE, journal of financial accounting researches, second year,No.2, serial No.4, summer 2010,page35-48 